\title{
CINTA TANAH AIR DALAM PERSPEKTIF PARTAI POLITIK
}

\author{
(Studi Kualitatif Cinta Tanah Air dalam Pandangan \\ Partai Politik PDIP Kabupaten Cirebon)
}

\author{
Harry Safari Margapradja \\ Dosen Universitas Muhammadiyah Cirebon \\ Email: harry.safari@umc.ac.id
}

\begin{abstract}
ABSTRAK
Cinta tanah air merupakan fitrah yang kokoh dan menjadi tabiat setiap manusia. Berpisah dari tanah air atau bahkan kampung halaman saja terasa berat dan terasa menyiksa. Dalam Tafsir al-Kabir, Juz XV, hal. 165; al-Imam Fakhr Al-Din al-Razi mengatakan bahwa; "Allah menjadikan meninggalkan kampung halaman setara dengan bunuh diri". Pernyataan al-Razi tersebut memgisyaratkan bahwa meninggalkan tanah air bagi orang-orang yang berakal adalah perkara yang sangat sulit dan berat, sama sebagaimana sakitnya bunuh diri. Jadi, cinta tanah air merupakan fitrah yang sangat dalam pada jiwa manusia. Partai politik dalam dunia perpolitikan, khususnya dalam politik lokal akan mudah dipahami dengan mengerti terlebih dahulu definisi partai politik.
\end{abstract}

Kata Kunci: Tanah Air, Partai Politik, PDIP

\section{ABSTRACT}

The homeland is a strong nature and becomes the character of every human being. Separating from the homeland or even the hometown feels heavy and tormenting. In Tafsir al-Kabir, Juz XV, p. 165; al-Imam Fakhr Al-Din al-Razi said that; "Allah made leaving his homeland equal to suicide". Al-Razi's statement implies that leaving the homeland to people of understanding is a very difficult and difficult matter, just as the suicidal illness. So, the love of the homeland is a very deep nature in the human soul. Political parties in the world of politics, especially in local politics will be easily understood by first understanding the definition of political parties. There are three theories that try to explain the origin of political parties.

Keywords: The Homeland, Political Parties, PDIP 


\section{PENDAHULUAN}

Cinta tanah air merupakan fitrah yang kokoh dan menjadi tabiat setiap manusia. Berpisah dari tanah air atau bahkan kampung halaman saja terasa berat dan terasa menyiksa. Sehingga harapan kembali ke tanah air atau kembali ke tempat tinggalnya membawa kesedihan apabila tidak menjadi kenyataan, sedangkan bila menjadi kenyataan akan terasa sangat membahagiakan.

Dalam pandangan Ahmad Ishomuddin tersebut, kecintaan kepada tanah air bukanlah kebodohan (jahiliyah), apalagi sebagai bentuk penyembahan kepada "berhala-berhala abstrak" sebagaimana berhala kasat mata yang dibuat dan disembah oleh kaum pagan. Kecintaan kepada tanah air bukanlah kemusyrikan (menyekutukan Allah). Cinta tanah air adalah sebagaimana menghormat bendera merah putih yang bukan berarti menyembahnya (Dikutip dari

http://www.nu.or.id/post/read/85342/beb erapa-dalil-tentang-cinta-tanah-air pada 31 Mei 2018 pukul 5.00 WIB).

Cinta tanah air juga merupakan sikap politik yang sudah mendarah daging bagi para pejuang kemerdekaan dan para pendiri bangsa. Pada saat negerinya dijajah, hatinya langsung tergerak, jiwanya berontak. Padahal, jika mereka mau, bekerjasama dengan penjajah akan lebih menguntungkan secara materi, jabatan tinggi sebagai abtenaar atau amtenar pun bisa diraih. Bangsa Indonesia yang terdiri dari beragam suku, ras, dan agama sangat rawan dipecah belah oleh penjajah dengan siasat devide et impera (politik pecah belah).

Kecintaan kepada tanah air membuat para pejuang bersatu, bahu membahu mengusir penjajah. Mereka menyadari sepenuhnya bahwa perbedaan suku, ras, dan agama sangat mudah dijadikan alat penjajah untuk memecah belah. Lantas perbedaan itu mereka jadikan sebagai kekayaan demografi untuk bersama-sama membebaskan bangsanya dari penjajahan (Dikutip dari https://geotimes.co.id/kolom/politik/politi k-cinta-tanah-air/ pada 31 Mei 2018 pukul 5.10 WIB).

Partisipasi politik rakyat menunjukkan partisipasi yang berbedabeda. Ada rakyat yang terlibat aktif, misalnya menjabat menjadi pejabat publik (pemerintah/birokrasi). Namun, ada juga rakyat yang tidak aktif dalam berpartisipasi, seperti tidak memilih dalam pemilu (golput). Perbedaan 
partisipasi politik rakyat itu disebabkan beberapa faktor. jika kita ingin mencapai partisipasi politik yang aktif maka rakyat perlu menumbuhkan kesadaran politik dan kepercayaan politik tinggi dan positif. Partisipasi politik yang aktif akan meningkatkan persatuan dan kesatuan seluruh warga negara dalam penyelenggaraan kehidupan bernegara.

Peran warga negara dalam bidang politik contohnya berupa hak warga negara untuk turut serta dalam setiap proses perubahan kebijaksanaan negara oleh para pejabat atau lembaga-lembaga pemerintah. Peran itu dilakukan sebagai wujud kebebasan hak asasi manusia sehingga dapat mengembangkan nilainilai demokratis. Pelaksanaan itu dijamin dalam Pasal 28 Undang-undang Dasar 1945. Isi dari pasal ini adalah seperti berikut ini: "Hak warga negara dan penduduk untuk berserikat dan berkumpul, mengeluarkan pikiran dengan lisan dan tulisan, yang akan diatur dengan undang-undang." (Dikutip dari http://cinta-tanah-air-kevinalgifary.blogspot.com/2016/04/belanegara-dalam-bidang-politik.html pada 31 Mei 2018 pukul 5.15 WIB).

Adapun rumusan masalah pada penelitian ini adalah;
Bagaimana partai politik menerapkan nilai-nilai cinta tanah air dalam kehidupan berorganisasi?

\section{LANDASAN TEORETIS}

Partai politik dalam dunia perpolitikan, khususnya dalam politik lokal akan mudah dipahami dengan mengerti terlebih dahulu definisi partai politik. Ada tiga teori yang mencoba menjelaskan asal usul partai politik. Pertama, teori kelembagaan yang melihat ada hubungan antara parlemen awal dan timbulnya partai politik, kedua, teori situasi historik yang melihat timbulnya partai politik sebagai upaya suatu sistem politik untuk mengatasi krisis yang ditimbulkan dengan perubahan masyarakat secara luas. Ketiga, teori pembangunan yang melihat partai politik sebagai produk modernisasi sosial ekonomi (Ramlan Surbakti, 1992:113).

Partai politik pertama lahir di negara-negara Eropa Barat. Dengan meluasnya gagasan bahwa rakyat merupakan faktor yang perlu diperhitungkan serta diikutsertakan dalam proses politik, maka partai- partai politik telah lahir secara spontan dan berkembang menjadi penghubung antara 
rakyat dan pemerintah (Bambang Sunggono, 1992:7).

Berangkat dari anggapan bahwa dengan membentuk wadah organisasi partai politik bisa menyatukan orang-orang yang mempunyai pikiran serupa sehingga pikiran dan orientasi mereka bisa dikonsolidasikan. Dengan begitu pengaruh mereka bisa lebih besar dalam pembuatan dan pelaksanaan keputusan (Miriam Budiardjo, 2008: 403).

Kemudian Sigmund Neumann (dalam Miriam Budiardjo, 2008:403) mengemukaan definisi partai politik sebagai berikut:

Partai politik adalah organisasi dari aktifitas-aktifitas politik yang berusaha untuk menguasai kekuasaan pemerintahan serta merebut dukungan rakyat melalui persaingan dengan suatu golongan atau golongan-golongan lain yang mempunyai pandangan yang berbeda (a political party is the articulate organization of society's active political agent; those who are concerned with the control of govermental policy power, and who complete for popular support with other group or groups

holding divergent view) (Miriam Budiardjo 2008:404).

Dalam Undang-Undang No.2 Tahun 2008 tentang partai politik pasal 1 ayat 1, partai politik didefinisikan sebagai organisasi yg bersifat nasional dan dibentuk oleh sekelompok warga negara Indonesia secara sukarela atas dasar kesamaan kehendak dan cita-cita untuk memperjuangkan dan membela kepentigan politik anggota, masyarakat, bangsa dan negara, serta mempelihara keutuhan Negara Kesatuan Republik Indonesia berdasarkan Pancasila dan Undang-Undang Dasar Negara Kesatuan Republik Indonesia Tahun 1945.

Dalam perspektif kelembagaan, partai politik adalah mata rantai yang menghubungkan antara rakyat dan pemerintah. Atau dalam bahasa lain, partai politik menjadi jembatan antara masyarakat sipil dengan pemerintah (Timothy, 1998:11). Sosiolog J.D Halloran yang juga pengamat komunikasi massa mengatakan, komunikator politik memainkan peran sosial yang utama, terutama dalam proses pembentukan suatu opini publik. Salah satu teori opini publik yang seluruhnya dibangun di sekitar komunikator politik, yaitu teori pelopor mengenai opini publik. Dalam hal ini menegaskan bahwa pemimpin menciptakan opini publik karena mereka berhasil membuat beberapa gagasan yang mula-mula ditolak, 
kemudian dipertimbangkan, dan akhirnya diterima.

Maurice Duverger dalam bukunya yang terkenal political parties, membagi sistem partai politik menjadi tuga bagian, yaitu sistem partai tunggal (one party system), sistem dwi partai (two party system) dan sistem multi partai (multi party system) (Budiharjo, 1982:162).

Sistem partai tunggal merupakan istilah yang menyangkal diri sendiri (contradiction in terminis). Sistem partai tunggal merupakan satu-satunya partai dalam suatu negara, maupun untuk partai yang mempunyai kedudukan dominan di antara partai lainnya. Pola partai tunggal terdapat di beberapa Negara Afrika (Ghana di masa Nkrumah, Guinea, Mali, Pantai Gading), Eropa Timur, dan RRC. Negara yang paling berhasil untuk meniadakan partaipartai lain ialah Uni Soviet.

Sistem dwipartai biasanya diartikan adanya dua partai atau adanya beberapa partai tetapi dengan peranan dominan dari dua partai. Contoh negara yang menerapkan sistem dwi partai yaitu: Inggris, Amerika Serikat dan Filipina. Sedangkan sistem multi partai adalah salah satu varian dari beberapa sistem kepartaian yang berkembang di dunia modern saat ini. Umumnya dianggap bahwa keanekaragaman dalam komposisi masyarakat menjurus ke perkembangannya sistem multi partai.

Dari uraian tersebut dapat disimpulkan bahwa partai politik merupakan sebuah organisasi yang dibentuk berdasarkan kumpulan orangorang yang memiliki kesamaan tujuan untuk mendapatkan sebuah kekuasaan dalam pemerintahan dan menjadi penghubung antara masyarakat sipil dengan pemerintah, yang memberikan informasi secara bottom up maupun top down

\section{METODOLOGI PENELITIAN}

Metode yang kami gunakan dalam penelitian ini adalah dengan metode kualitatif. Metode kualitatif adalah metode yang lebih menekankan pada aspek pemahaman secara mendalam terhadap suatu masalah dari pada melihat permasalahan untuk penelitian generalisasi.

Metode penelitian ini lebih suka menggunakan teknik analisis mendalam (in-depth analysis), yaitu mengkaji masalah secara kasus perkasus karena metodologi kualitatif yakin bahwa sifat suatu masalah satu akan berbeda dengan sifat dari masalah lainnya. Tujuan dari 
metodologi ini bukan suatu generalisasi tetapi pemahaman secara mendalam terhadap suatu masalah. Penelitian kualitatif berfungsi memberikan kategori substantif dan hipotesis penelitian kualitatif.

Bogdan dan Tailor seperti yang dikutip oleh Moeleong, mendefinisikan metodologi kualitatif sebagai prosedur penelitian yang mengha- silkan data deskriptif berupa kata-kata ter- tulis atau lisan atau dari bentuk tindakan kebijakan (Moeleong, Lexy J. 2002:112).

Dalam mengumpulkan data serta informasi yang diperlukan dalam penelitian ini, penulis menggunakan teknik wawancara dan studi literatur. Data yang yang dikumpulkan berupa pertama langsung dari sumbernya, peneliti menjadi bagian dari instrumen pokok analisisnya, kedua data berupa kata-kata dalam kalimat atau gambar yang mempunyai arti (Sutopo, 2006:40).

\section{PEMBAHASAN}

Penerapan nilai-nilai cinta tanah air dalam kehidupan berorganisasi sebagaimana diungkapkan Ketua DPC PDIP Kabupaten Cirebon, H. Mustofa menuturkan, setidaknya ada dua hal yang mendasari nilai-nilai cinta tanah air dalam kehidupan berorganisasi bagi kader dan simpatisan PDIP Kabupaten Cirebon yang sejalan dengan apa yang telah digariskan oleh pengurus pusat, di antaranya;

1) Mewujudkan pemerintahan yang bersih. Partai Demokrasi Indonesia Perjuangan mengeluhkan adanya beberapa kepala daerah yang tak setia kepada partai pengusung. Mereka ingkar janji pada partai pengusung dengan cara pindah ke partai. Perilaku ingkar janji tersebut tentu bukan pendidikan politik yang baik bagi rakyat. Selain itu, perilaku ini tentu saja merugikan partai pengusung yang telah menyiapkan program visi misi untuk kesejahteraan rakyat dan telah mengerahkan seluruh sumberdaya untuk memenangkannya di pemilu daerah.

Lemahnya etika dari para politisi ini berbahaya karena bisa mengantar pada perilaku pelanggaran hukum, salah satunya korupsi. Tindakan korupsi yang masih akut di negeri ini juga disebabkan lemahnya etika dan kesantunan di dunia politik kita. Menurutnya, membangun pemerintahan yang bersih (zero tolerance) terhadap korupsi dan $\mathrm{KKN}$ merupakan salah satu butir Panca Prasetya kepada Rakyat yang harus ditandatangani calon kepala daerah dari PDIP. Mereka, calon kepala daerah dari 
PDIP diwajibkan menandatangani Pancaprasetya.

2) Revolusi mental. Revolusi mental bisa diartikan sebagai perubahan mendasar (fundamental) dalam struktur kekuatan atau organisasi yang terjadi dalam periode waktu yang relatif singkat. Secara mendasar, ada delapan prinsip revolusi mental, yaitu:

a. Revolusi Mental adalah gerakan sosial untuk bersama-sama menuju Indonesia yang lebih baik,

b. Harus didukung oleh tekad politik (political will) Pemerintah,

c. Harus bersifat lintas sektoral,

d. Kolaborasi masyarakat, sektor privat, akademisi dan pemerintah,

e. Dilakukan dengan program "gempuran nilai" (value attack) untuk senantiasa mengingatkan masyarakat terhadap nilai-nilai strategis dalam setiap ruang publik,

f. Desain program harus mudah dilaksanakan (user friendly), menyenangkan (popular) bagi seluruh segmen masyarakat,

g. Nilai-nilai yang dikembangkan terutama ditujukan untuk mengatur moralitas publik (sosial) bukan moralitas privat (individual), h. Dapat diukur dampaknya dan dirasakan manfaatnya oleh warga masyarakat.

Kendala yang dihadapi dalam penerapan nilai-nilai cinta tanah air dalam berorganisasi:

1. Kurangnya kesadaran untuk mengutamakan kewajiban daripada hak,

2. Lemahnya sistem peradilan di Indonesia,

3. Kurang partisipasi aktif dalam pembangunan Negara,

4. Kurangnya kesadaran mengamalkan nilai-nilai pancasila,

5. Pengaruh negatif globalisasi yang menimbulkan hedonisme, individualisme dan budaya instan,

6. Kurang meratanya kesejahteraan bagi seluruh rakyat Indonesia,

7. Kurangnya rasa dbngga akan produk atau budaya asli Indonesia.

Adapun upaya yang dilakukan untuk menumbuhkan kesadaran cinta tanah air:

1. Meluaskan wawasan tentang
sejarah Indonesia serta
perjuangan para tokohnya,


2. Menjaga kerukunan dalam kehidupan beragama, bermasyarakat, berbangsa, dan bernegar,

3. Menumbuhkan semangat nasionalisme dalam diri,

4. Bangga menggunakan produk/budaya asli dan melestarikannya,

5. Menyaring budaya asing yang masuk sesuai dengan kepribadian bangsa Indonesia.

Menerapkan budaya hemat, pola hidup sederhana dan tepaselira antarsesama.

\section{SIMPULAN}

Secara sederhana, penelitian ini dapat disimpulkan sebagai berikut:

1. Pada masa sekarang, gema Sumpah Pemuda masih menjiwai kehidupan bangsa Indonesia, yang sedang membangun demi masa depannya. Semangat persatuan dan kesatuan senantiasa menjadi landasan bagi bangsa Indonesia dalam kehidupan bermasyarakat, berbangsa dan bernegara serta dalam kehidupan antar bangsa. Cinta tanah air telah dibuktikan oleh bangsa Indonesia dalam membela bangsa dan tanah airnya ketika melawan Belanda yang berusaha menjajah kembali Indonesia.

2. Arus informasi yang semakin pesat mengakibatkan akses masyarakat terhadap nilai-nilai asing yang negatif semakin besar. Apabila proses ini tidak segera dibendung, akan berakibat lebih serius ketika pada puncaknya masyarakat tidak bangga lagi pada bangsa dan negaranya. Pada genersi muda hal ini merupakan masalah yang serius karena mereka adalah tunas penerus bangsa, yang jika tidak dibendung akan mengancam eksistensi dan ciri luhur bangsa ini.

3. Peningkatan kesadaran masyarakat akan nilai-nilai luhur budaya bangsa adalah sarana untuk membangkitkan semangat nasionalisme dan cinta tanah air, yang dapat dilakukan dengan senantiasa memupuk rasa persatuan dan kesatuan bangsa dan bernegara dalam kehidupan bermasyarakat. Kehendak bangsa untuk bersatu dalam wadah negara kesatuan Republik Indonesia merupakan sarat utama dalam mewujudkan nasionalisme nasional. Dengan demikian, tidak pada tempatnya 
untuk mempersoalkan perbedaan suku, agama, ras, budaya dan golongan. Kehendak untuk bersatu sebagai suatu bangsa memiliki konsekuensi siap mengorbankan kepentingan pribadi demi menjunjung tinggi nilai-nilai persatuan dan kesatuan. Tanpa adanya pengorbanan, mustahil persatuan dan kesatuan dapat terwujud. Malah sebaliknya akan dapat menimbulkan perpecahan.

\section{DAFTAR PUSTAKA}

Meleong, Lexy. 2002. Metode Penelitian Kualitatif. Bandung: Remaja Rosdakarya

Surbakti, R. 1999. Memahami Ilmu Politik. Jakarta: Grasindo

Sutopo, HB. 2006. Metode Penelitian Kualitatif. Surakarta: UNS.Press

Jurnal Ilmiah Pendidikan Pancasila dan Kewarganegaraan, Th. 1, Nomor 1, Juni 2016

JIPPK, Volume 2, Nomor 2, Halaman 108-114

\section{Website:}

http://www.nu.or.id/post/read/85342/beb erapa-dalil-tentang-cinta-tanah-air Dikutip pada 31 Mei 2018 pukul 5.00 WIB.

https://geotimes.co.id/kolom/politik/politi k-cinta-tanah-air/
Dikutip pada 31 Mei 2018 pukul 5.10 WIB

http://cinta-tanah-air-kevinalgifary.blogspot.com/2016/04/belanegara-dalam-bidang-politik.html Dikutip pada 31 Mei 2018 pukul 5.15 $W I B$ 